\title{
CHAPAEV AS A MEDIA OBJECT: FROM THE CIVIL WAR TO THE BLACK LIVES MATTER MOVEMENT
}

\author{
Daniil A. Anikin \\ Lomonosov Moscow State University | Saratov State University. Moscow, Russia. \\ Email: dandee[at]list.ru
}

\begin{abstract}
The article explores the dynamics of the image of V.I. Chapaev in the Soviet and postSoviet media space. Using the theory of post-memory by M. Hirsch and S. O'Donoghue as methodology of research, the author analyzes the transformation of the main characteristics of the image, its place in Russian historical memory and in the cultural tradition. V.I. Chapaev became one of the most significant characters in the Soviet cultural tradition. After the fall of the Soviet Union the image of Chapaev however retained its significance in the context of rethinking the Soviet heritage. The article highlights the following stages of transformation of V.I. Chapaev's image: the inclusion in the "founding myth" and gradual transformation into a Soviet epic hero (crowding out collective trauma); debunking the heroic status within the framework of the "carnival culture" and turning into a character of anecdotes (de-traumatization in the process of post-memory formation); transformation into a hero of Internet memes (transformation of post-memory and de-actualization of the themes of the Civil War). The author argues that the burst of memes depicting Chapaev in 2020 demonstrates a post-ironic attitude to the Black Lives Matter movement in Russian society. The author concludes that the fact that Chapaev's image was included in a fundamentally different political and cultural context demonstrates that the symbolic potential of the Civil War memory in Russia is entirely exhausted and can no longer serve as a tool for the formation of commemorative practices.
\end{abstract}

Keywords

media; historical memory; post-memory; post-irony; meme; Chapaev; Civil War

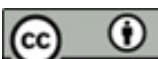

This work is licensed under a Creative Commons «Attribution» 4.0 International License 


\title{
ЧАПАЕВ КАК МЕДИА-ОБЪЕКТ: ОТ ГРАЖДАНСКОЙ ВОЙНЫ К ДВИЖЕНИЮ BLACK LIVES MATTER
}

\begin{abstract}
Аникин Даниил Александрович
Московский государственный университет им. М. В. Ломоносова | Саратовский национальный исследовательский университет имени Н.Г. Чернышевского. Москва, Россия. Email: dandee[at]list.ru
\end{abstract}

\section{Аннотация}

В статье исследуется динамика образа В. И. Чапаева в советском и постсоветском медиапространстве. На основании методологии изучения пост-памяти М. Хирш и С. О'Донахью анализируется трансформация основных характеристик образа, выявляется его место в российской исторической памяти и в культурной традиции. В.И. Чапаев стал одним из наиболее значимых персонажей советской культурной традиции, а после распада Советского Союза его образ сохранил свое значение в контексте переосмысления советского наследия. В статье выделяются следующие стадии трансформации образа В.И. Чапаева: включение в состав «мифа основания» и постепенное превращение в советского эпического героя (вытеснение коллективной травмы); развенчание героического статуса в рамках «карнавальной культуры» и превращение в персонажа анекдотов (детравматизация в условиях формирования пост-памяти); актуализация в качестве героя интернет-мемов (трансформация пост-памяти и деактуализация тематики Гражданской войны). Включение образа в принципиально иную политическую и культурную повестку демонстрирует исчерпание символического потенциала памяти о Гражданской войне в качестве инструмента формирования определенных коммеморативных практик. Автор приходит к заключению что тот факт, что образ Чапаева оказался включен в принципиально иной политический и культурный контекст демонстрирует, что символический потенциал памяти о Гражданской стране в России окончательно исчерпан и не может больше служить инструментом формирования коммеморативных практик.

\section{Ключевые слова}

медиа; историческая память; пост-память; пост-ирония; мем; Чапаев; Гражданская война

Это произведение доступно по лицензии Creative Commons «Attribution» («Атрибуция») 4.0 Всемирная 


\section{FORMULATION OF THE PROBLEM}

2020 is of great importance in the Russian politics of commemoration, because, along with the 75th anniversary of the Victory in the Great Patriotic War, the country celebrates the 100th anniversary of the end of the Civil War, which relates to the evacuation of the troops of P.N. Wrangel from the Crimea.

Of course, we are talking exclusively about the political marking of this event, since the Civil War lasted until 1922, and, in a sense, it can be included in its composition and the fight against the Basmachi movement in Central Asia. The symbolic significance of linking the end of the Civil War with the defeat of Wrangel should be associated with the analogy between the annexation of Crimea to the Soviet state in 1920 and the reunification of Crimea with the Russian Federation in 2014.

It is not surprising that the anniversary of this event becomes a pretext for perpetuating the memory of the Civil War, despite the fact that there is no common position in the public consciousness regarding this event. Official political actors emphasize the educational significance of the Civil War, that is, the inadmissibility of internal political confrontation, but the issue of reflecting this position in the memorial landscape is also devoid of any uniformity. The culmination of this attitude to the Civil War was to be the construction of the Monument of Reconciliation in Sevastopol in November 2020. The opening date of which symbolically refers to the anniversary of the evacuation of the troops of P.N. Wrangel. Due to the complex epidemiological situation and the banal unrediness of the monument, the event was postponed to a later date. It becomes very indicative in a figurative sense - reconciliation, which the authorities insist on, is once again postponed (Vasiliev, 2020). This is a sign of the lack of clarification of the causes and consequences of the Civil War in historical science. But to an even greater extent, it is a symptom of internal divisions in modern Russian society, which cannot fully determine its attitude to the events of the recent past.

Nevertheless, another monument directly referring to the events of the Civil War was unveiled in October 2020 in the village of Krasnoy, Orenburg District. The monument was the bust of Cossack Colonel Timofey Sladkov, who actively participated in the fight against the Bolsheviks and remained in history thanks to one cavalry raid, during which the headquarters of the 25th Infantry Division of the Red Army was defeated, and its commander, Vasily Chapaev, died. The unexpected angle of the installation of the monument was given by the fact that it was erected just on the street bearing the name of Chapaev. It gave another reason to think about the bizarre interweaving of the Russian past and present (Shcherbakova, 2020). The issue actively dis- 
cussed in the media has several dimensions, two of which are worth noting the ethical and political ones. In the ethical aspect, the desire, after a whole century, to confront two participants of the legendary battle again becomes strange as it was the last fight for one of them. In the political aspect, it becomes interesting not only to analyze the political actors behind the creation of an alternative version of the Civil War (in particular, the bust of Sladkov is installed on the territory that formally belongs to the local church), but also to identify those cultural frameworks that transforms the Soviet version of the memory of these events.

Does the competition of monuments and toponymics mean the preservation of the traumatic interpretation of the Civil War in modern Russian society? At first glance, this understanding is quite correlated with the cautious actions of the Russian authorities, avoiding reasons for public controversy about the causes and consequences of the post-revolutionary civil confrontation in Russia. But the significant question remains how much the images of the characters of the Civil War remain relevant symbolic capital for modern Russian society, how much is the use of their images in the media or Internet culture a reproduction of the ongoing worldview divisions, or, conversely, only evidence of turning into cultural stamps?

Within the framework of this article, the subject of the study will be the image of one of the Soviet heroes of the Civil War, Vasily Chapaev, in the conditions of post-Soviet reality, his transformation from the character of Soviet jokes into a kind of meme, the use of which goes far beyond the ideological differences of supporters and opponents of Soviet power. The purpose of the article is to determine the role of the memory of the Civil War in modern Russian society (on the example of using the image of Chapaev in folklore and post-folklore).

Addressing Chapaev's figure is no coincidence, since his figure is uniquely present in several cultural formations at once: in the classical Soviet epic of the 20-30s, in the late Soviet ironic culture, as well as in modern Internet folklore as one of the popular memes. The very presence of Chapaev in each of these cultural contexts nevertheless raises not only the question of the continuity of the historical memory of the Civil War, but also its nonlinear dynamics, gaps and shifts in the understanding and use of the past.

To achieve this goal, it is necessary to determine methodological toolkit, to reveal the evolution of Chapaev's image in Soviet and post-Soviet culture, as well as analyze the specifics of Internet culture in terms of the functioning of folklore images in it. 


\section{RESEARCH METHODOLOGY}

From a methodological point of view, M. Hirsch's works on post-memory are of great importance for analyzing the evolution of the image of a historical character. In her book on Holocaust Post-Memory Shaping, she focuses on how the compilation of visual images through cinematography determines the emotional perception of the past that goes beyond the "living" human memory. Visualization leads to a peculiar effect, when certain images of the past become more visible and significant for subsequent generations than for their parents or more distant ancestors (Hirsch, 2012, p. 14-16).

Developing the ideas of M. Hirsch, S. O'Donoghue applies the concept of post-memory to the analysis of literary representations of the Spanish Civil War. From his point of view, this form of memory concentrates on traumatic events, creating a new form for their expression. Moreover, it is precisely the artistic representation of the distant events of the Spanish Civil War that becomes a powerful civil gesture, as it makes us return to those events again, look for new forms of their symbolic settlement (O'Donoghue, 2016). A significant clarification is only the fact that the post-memory sets a new framework for the perception of the past, which significantly changes the historical picture that was developed at a certain moment in time. This framework can serve to actualize those meanings that have been "displaced" as a result of ideological manipulations. It can also create new artistic images that are only indirectly related to those historical events that were reflected in the post-memory. In other words, the historical image, which has become an artistic character due to the circumstances, acquires its own existence and it is often extremely far from the real details of the life and death of its prototype.

Considering the specifics of the analyzed material, both from a substantive and a formal point of view, the use of philological literature for the analysis of the image of V.I. Chapaev is of great importance. K. Clark in his work on the Soviet novel identifies the plot and stylistic aspects that contributed to the assertion of Chapaev as an important element of the socialist founding myth (Clark, 2002, p. 43-44). B. Seth, who devoted the work to the evolution of the Soviet anecdote, emphasizes that not a literary, but a visual text played a large role in the formation of the myth about Chapaev. It was the famous film "Chapaev" of 1934 that became a precedent text for all mature and late Soviet culture, significantly transforming the heroic image that was formed in Soviet ideology (Seth, 1990, p. 48). As M. Odesskiy notes, it would be more correct to say that Chapaev became the hero of a number of myths - an epic, a Soviet, a Stalinist ones, and only then turned into a character of anecdotes and ironic rethinking (Odesskiy, 2007).

For the study of the modern image of Chapaev, literature on anthropology is of great importance, in particular, articles on the problem of the func- 
tioning of folklore material in the Internet environment. The articles of S.Y. Neklyudov (Neklyudov, 1995), which raise the question of the specifics of post-folklore, especially in the context of the formation of a specific Internet culture, are of important methodological importance. To study the transformation of epic characters in post-folklore, it is worth turning to the works of A. S. Arkhipova, which especially understand the case of "film-dependent jokes" that are directly related to the image of Chapaev (Arkhipova, 2003; Arkhipova, 2020).

Within the framework of humor studies, works on the ratio of humor and traumatic memories are of great importance for this topic (Nevo, Keinan, Teshimovsky-Arditi, 1993; Hudak, Dale, Hudak, DeGood, 1991). According to these authors, humor performs a dual function. On the one hand, it contributes to abstraction from traumatic memories, but on the other hand, it is able to cause a repeated experience of a traumatic situation. However, it is worth noting that these conclusions were made by the authors when studying individual rather than collective injuries.

It is the understanding of the ambiguity and non-linearity of Chapaev's biography as an object of historical commemoration that makes us turn to the question of why he was in demand as a Soviet hero, what significant stages can be distinguished on the way of turning a real biography into a mythological narrative.

\section{SOVIET "FOUNDING MYTH" AND THE IMAGE OF VASILY CHAPAEV}

The formation of the Soviet system caused the need to form a "founding myth," which was the October Revolution of 1917, as well as the Civil War, which became a symbolic confrontation between the two antipodes - the side of good (Bolsheviks) and the side of evil (all their opponents, despite the internal contradictions between them). In this sense, the Civil War became an analogue of the US War of Independence, as a result of which not only a new political system was developed, but also national mythology was formed, in particular, the myth of the "founding fathers."

In the Soviet state there was an interesting pattern when the heroes of the Civil War began to claim the role of such founders with good reason. Since the composition of the political elite of Soviet power underwent significant changes in the first twenty years of its existence, the winning position was given not to those participants of the Civil War who were able to survive in it, but to those who died. The living heroes of the war risked taking the wrong political step, taking the wrong side in the internal party coalitions, while the dead heroes remained the eternal guarantors of Soviet power, regardless of which political configuration it acquired. 
Already in the 1920s, that is, only a few years after the end of the Civil War, the pantheon of heroes who gave their lives for Soviet power began to take shape. It is significant that almost immediately the process of forming the memorial canon was closely intertwined with the struggle for real political power among the representatives of the Soviet elite.

Among the representatives of the command staff of the Red Army during the Civil War, Vasily Chapaev did not occupy the most important place, so his death during the Cossack raid at first did not receive close attention from the Soviet government.

Chapaev's fate was in the spotlight after the release of D. A. Furmanov's novel "Chapaev", in which the epic status of the protagonist was successfully combined with the needs of the emerging socialist mythology. D. A. Furmanov himself, as far as one can judge from the diary entries, was quite wary of V.I. Chapaev, but the image he created turned out to be not only convincing, but also very popular. The newly formed Soviet system, which had rejected the pre-revolutionary heroic pantheon, needed its own heroes. Moreover, it needed not only heroes, but also martyrs with their lives paving a bright path to communism. Chapaev (of course, not as a real historical character with a difficult personal life and a problematic biography, but as a literary hero) was perfect for this role.

It is worth noting that the first half of the 1920s, as K. Clark notes, was just the time when not only the literary canon of the Soviet novel but also memorial practices that legitimized the new political and cultural order were formed (Clark, 2002, p. 21). Together with Chapaev, other heroes of the Civil War entered this canon, either who died during the fighting or who passed away immediately after its end and therefore did not have time to spoil their combat biography with the difficulties of post-war life. Therefore, the novel by D.A. Furmanov, published in 1923, set the social "ritual" that was supposed to reproduce the memory of the Civil War, but additional political circumstances were required so that the secondary commander of the Red Army, even if he became the hero of the work of art, could claim a special place even in this heroic pantheon.

The fact is that the second half of the 1920s was a time of fierce political struggle between I.V. Stalin, absent from the pantheon of heroes of the Civil War and L. Trotsky, who was the People's Commissar (Minister) for military and naval affairs in 1918-1925. The commemoration of the Civil War became dangerous for I.V. Stalin, since it meant an increase in the symbolic capital of his main political opponent, but that is why at that time the emphasis in the representation of the revolutionary past shifted towards the glorification of the direct participants in the hostilities. The exaggerated emphasis on the role of V.I. Chapaev, G.I. Kotovsky, N.A. Shchors in the defeat of the anti-Soviet 
forces automatically meant "belittling" the significance of L. Trotsky as the chief strategist and ideologist of military operations.

It is not surprising that such importance was attached to the creation of the "correct" cinematic representation of the Civil War, which was supposed to consolidate not only the status of the heroes, but also, indirectly, the status of I.V. Stalin himself in the mass consciousness. This is exactly the role played by the film "Chapaev," shot in 1934 and awarded in 1935 the prize of the I Moscow Film Festival, the jury of which was headed by S. Eisenstein.

The literary myth was replaced by the cinematic myth, which was gaining great popularity in the mass consciousness. Chapaev in the film was finally separated from his prototype, acquiring the features of the people's leader, whose death became the reason for the new military triumph of his army. The memory of Chapaev, preserved in the local narratives of his family and former fighters, was replaced by a post-memory, which, however, has a much more massive effect. M. Odessky cites the story that Chapaev's son once visited the Cinema Museum, the staff of which concluded that he was not at all like his famous father and only a little later they realized that he did not look like the actor, B.A. Babochkin, who had played the main role in the film "Chapaev." As in the case of "Alexander Nevsky" by S. Eisenstein, the cinematic image of the protagonist was so convincing that it became a prototype for all subsequent images (Schenk, 2007, p. 387-389).

Of course, such an image becomes an important element of Soviet (and more specifically, Stalinist) ideology, not only defining the contours of a new collective identity, but also forming the image of a "new person" - an ideological fighter for the achievement of communism. It was the abstraction and detachment of the hero, along with the frenzied popularity of the film itself, which instantly spread to quotes and became one of the first examples of the precedent text in Soviet culture that became a factor in the subsequent transformation of Chapaev's image.

According to D. L. Bykov, "The civil war remains the last topic of the Russian heroic epic. They tried to make Zhukov a national hero - but he was far from Chapaev's glory: there was, apparently, something in Zhukov that did not allow him to become his own. Chapaev is the last truly people's commander: probably because, despite all his military wisdom, he was in battle in the most dangerous place "(Bykov, 2020). This judgment seems too sharp, but the epic and folklore nature of Chapaev's image is one of the significant factors in his effectiveness as a symbol of the "national hero." It is worth noting that according to A.S. Arkhipova, it is worth distinguishing the cinematic image of Chapaev, which does not allow him a humorous interpretation, and subsequent film-dependent jokes about Chapaev, which became an ironic reaction to completely different political and cultural conditions (Arkhipova, 2003, p. 15-16). 


\section{FROM EPIC TO ANECDOTE: AN IRONIC RETHINKING OF CHAPAEV'S IMAGE}

In the 60s of the XX century, there was a repeated appeal to the theme of the Civil War, which was caused by the desire of the political elite to level negative memories of Stalin and recreate the original Soviet myth. In the media environment, this was reflected in the emergence of a number of films reconstructing individual episodes of the Civil War, for example, «The Elusive Avengers» (1966), «New Adventures of the Elusive» (1968), «Adjutant of His Excellency» (1969), «Dangerous Tour» (1969), but offering a completely different aesthetic. The heroic pathos of revolutionary literature and cinematography was replaced by an adventurous lightness, combined with an ironic attitude to both the characters of the films themselves and the reality of the Civil War. Although Chapaev himself became the hero of one of these films (the film "Chapaev's Eagles" (1968)) only indirectly but his image was also significantly influenced by the new aesthetics.

A. S. Arkhipova notes that the re-release in cinemas of the restored film "Chapaev" in 1966 was of great importance. "Remember the White Sun of the Desert, Sukhov returns home and he does not want to participate in anything at all, but against his will he is always drawn in. And the restored film about Chapaev was very contrary to this idea - such a brave, rude, brutal voyage with a checkerboard. This then, apparently, caused, rather, an effect not heroic, but a comic effect." (Archirova, 2020).

The folk "carnival culture," which M. M. Bakhtin attributed the property of a unique antidote to excessive ideologization to, made the image of Chapaev the object of irony, reflected in numerous anecdotes (Bakhtin, 1990). The very change of narrative allows us to talk about Chapaev's transition to a new cultural layer, which S. Y. Neklyudov called "post-folklore" (Neklyudov, 1995, p. 4-6) In his opinion, post-folklore is fundamentally different from both popular and elitist culture, meaning the emergence of a new syncretic cultural layer, which is the generation of urbanized and technologically developed

The main features of post-folklore include polycentricism, fragmentation, transparency and relative marginality in relation to ideology. Polycentricism and fragmentation are directly related to the peculiarities of the social structure of an urbanized society, in which various narratives of a folklore, literary or ideological nature overlap each other. Transparency is manifested in the fact that post-folklore texts within a certain social segment do not form a closed tradition, penetrating into other communities, even if as separate elements.

The question of ideological marginality seemed more complex. S. Y. Neklyudov himself believes: "Post-folklore - again, unlike peasant folklore - is usually ideologically marginalized, since the fundamental ideological needs of cit- 
izens are satisfied in other ways, they have no direct relation to the oral tradition (by the media, to a lesser extent - cinema and other spectacles, even less popular literature)" (Neklyudov, 2016) But due to the lack of dominant ideology in post-folklore texts, they cannot be considered completely non-ideological, since the very fact of using ideological stamps outside the context of their official use already makes post-folklore instruments of desacralization of official discourse.

Chapaev's humorous image in anecdotes, as in examples of post-folklore texts, contributes to the desacralization of not only the hero himself, but also the official discourse within which his heroic nature was possible. A. S. Arkhipova believes that it is film-dependent jokes about Chapaev that become an important narrative, within the framework of which it becomes possible to debunk many other "Soviet myths," for example, the confrontation between the USSR and the USA, the high status of state security bodies, etc. (Arkhipova, 2020).

The mythologized image of the Soviet hero, who spared no effort to fight the enemy, was replaced by the equally mythologized image of an inventive, but not always successful commander, accompanied by a loyal orderly Petka and no less loyal Anka, the machine gunner. Several significant patterns can be seen in such a transformation. First, the natural disappearance of those life realities that were well known to the generation of the 30s led to a symbolic re-coding of the meaning of those quotes and episodes from the film, which turned into a precedent text of Soviet culture. Having got rid of the ideological frame that cinema gave them, the fragments acquired their own autonomous existence, finally ending any references to the real existence of the prototype.

Second, the image of Chapaev turns into the embodiment of an ironic attitude to Soviet reality, which is manifested even in the neutralization of the initial opposition of friends and foes. It was fundamentally important for the Soviet "founding myth" that the hero-martyr could die only at the hands of the enemy, who was understood not so much as a personal opponent, but as a symbolic "evil." The symbolic designation of the enemy as "white" passed from the everyday vocabulary of the Civil War era into the book, and then into the film (the White Army, in contrast to the Red Army, was named the armed forces that advocated the overthrow of the Soviet government, regardless of what political orientation they adhered to). But after the Great Patriotic War the negative areola around the image of the "Whites" decreased significantly, since "fascists" began to be perceived as the main embodiment of evil. The "Whites," as Chapaev's main opponents, ceased to represent "absolute evil," becoming, in fact, only a faceless mass against the background of which the action of the jokes took place. 
Paradoxically, Chapaev became almost the only character of the Civil War era who had managed to safely overcome all the political vicissitudes of Soviet history. The Stalin era meant a "reassembly" of the revolutionary canon, as a result of which a number of participants in the Civil War were deleted from official historical memory except K. E. Voroshilov and S. M. Budyonny who belonged to a narrow circle of the political elite close to Stalin. In the conditions of the Khrushchev "thaw" many heroes of the Civil War, who were repressed under Stalin, returned to Soviet memorial culture. For example, in many cities in the 60s, streets named after M. N. Tukhachevsky, V. K. Blucher and other Soviet military leaders appeared. It is clear that the commanders who discredited themselves by participating in Stalinist repressions took a more marginal position in public space. But until the end of the existence of the Soviet Union Chapaev remained one of the most recognizable and politically neutral heroes of the early Soviet era, which was largely facilitated by his transformation into a hero of anecdotes.

Chapaev turns out to be a convenient character for a humorous rethinking of the trauma of the Civil War, since his image is in no way connected with more relevant traumatic memories of repressions or the consequences of World War II. And the uncertainty quite corresponding to the folklore status of the character regarding the completion of the life path creates in late Soviet society the opportunity for the appearance of a series of jokes about the "red" commander, as if he had safely survived the Civil War. In this sense, the image of Chapaev performs the function of desacralization not only of the character himself, translating his existence from a situation of folklore to a situation of post-folklore, but also of commemoration practices of Soviet society, trying to actualize the "myth of foundation." In the era of the late Soviet Union, the memory of the Civil War is already becoming a post-memory, but active attempts to actualize it in the official cultural narrative are offset by an ironic attitude towards the characters of that era, which is clearly manifested on the example of Chapaev.

\section{CHAPAEV AND BLACK LIVES MATTER IN THE RUSSIAN MEDIA SPACE: BETWEEN POST-FOLKLORE AND NETLORE}

In the post-Soviet media space, Chapaev continued his existence in an ironic way. His image was used in several computer games, as well as in the famous novel by V. I. Pelevin "Chapaev and Void" (US: Buddha's Little Finger", UK: "Clay Machine Gun")." It is worth making a reservation that a meme is a culturally significant unit of information, so the very existence of memes cannot be reduced to either Internet culture or Internet humor. As N. A. Zinovieva notes, "the phenomenon of memes is interdisciplinary and multifaceted, and even if we consider only those memes that are information prod- 
ucts, we will see many objects, among which will be advertising images, images and slogans, quotes from films and literature, famous works of art and many random objects and idioms that have suddenly gained popularity, and, of course, Internet memes" (Zinovieva, 2016, p.114) Internet memes are only vivid and visual, but far from the only manifestation of the ability of information to crush and mix. It is natural that Internet memes are closely related to folklore and post-folklore, representing a kind of transformation of images already available in the cultural narrative. But the transformation of a certain image into an Internet meme does not mean that the information encoded in it is kept unchanged.

The question of the specifics of Internet folklore seems quite debatable. So, R. Dorson in his article prefers to talk about "facelore," beating the consonance of the words "folk" and "face" and emphasizing that Internet reality creates a space for mixing truth and lies, reliable facts, probabilistic hypotheses and implausible fiction (Dorson, 2004, p. 281).

D. Werner notes that the main similarities between Internet folklore and the usual ways of disseminating folklore texts (for example, anecdotes) are the viral nature of distribution, spontaneity, anonymity, high transmission speed (Werner, 2003) In this sense, jokes about Chapaev did not go anywhere in virtual space, they continue to exist and spread, although the question of generational differences in their perception remains interesting.

N. A. Zinovieva believes that the key feature of Internet folklore is the dominance of creolized texts in it, which mean objects consisting of two nonhomogenic parts - verbal and non-verbal (Zinovieva, 2016, p. 114). In other words, most of the Internet memes offer a combination of text and its visualization, which contributes to the better absorption of broadcast information by the audience. That is why Internet memes with Chapaev most often appear in the form of creolized texts, the non-verbal part of which is a frame from the film, and the verbal is a direct quote or indirect reference. Of course, symbolic recoding of such a meme is achieved by changing the entire verbal or nonverbal part, or by changing individual elements thereof.

Chapaev's image in the conditions of Internet culture breaks away from the context of the Civil War, preserving only certain attributes, for example, enmity with the "whites," which are being rethought in a new socio-cultural and political meaning. This property of Internet folklore is noted on the example of I. V. Stalin and the attributes associated with him (tobacco pipe, mustache) N. B. Gramatchikova and T. I. Khoruzhenko (Gramatchikova, Khoruzhenko, 2017, p. 26). Visual quotes from the film became widespread as Internet culture spread, turning into numerous memes. In particular, the demonstration of the famous scene from the film "Chapaev" where the main 
character said the phrase: "Here, Petka, we will kill all the" whites", then we shall live!" became a popular meme.

The ironic meaning of this phrase is given by the symbolic recoding of the key opponent of the"Whites". If in the original context, perfectly understandable for the Soviet viewer, the "Reds" (soldiers of the Soviet Red Army) act as such an opponent, then in the conditions of the de-actualization of such a confrontation, the image of the opponent also changes. Instead of the "Reds," the "Blacks" become such an opponent, and the phrase itself acquires an initially unusual "American" meaning, since Vasily Chapaev acts as a defender of the African-American population of the United States.

But if in the 90s such a meme was an example of irony built on the placement of Chapaev's image in an initially unusual context, then the information agenda of 2020 has set a new trend in creating memes about Chapaev, or, more precisely, a new way of reading and interpreting them.

One of the information trends of the year, demonstrating its social significance even against the background of the pandemic, was the Black Lives Matter movement, which became widespread not only in the United States, but also almost all over the world. The appeal of this movement to the democratic values of legal equality and freedom made it the source of a number of flash mobs and symbolic acts aimed at supporting the values declared by the BLM (for example, standing of participants in sports competitions on one knee). At the same time, a certain character of symbolic pressure, forcing not only to agree with the values of this movement, but also with a specific form of their expression, caused an ambiguous reaction in the world, which manifested itself in the emergence of memes. It is interesting that the main source of memes expressing a dual attitude to the BLM movement for Russia was the image of Chapaev.

The use of the image of Chapaev in memes dedicated to the Black Lives Matter movement means his transition to a new high-quality level: from irony to post-irony.

If irony is a rhetorical technique in which there is a discrepancy between the explicit and hidden meaning of the statement, then the post-irony demonstrates the blurring of the boundaries between ridicule and truth, when the statement becomes ambivalent in nature that does not contain an unambiguous interpretation. We can say that post-irony, in many ways, becomes a sign of a new social reality, in which not only clear boundaries are absent, but the very attitude to any phenomenon cannot be unambiguous. Irony means a clearly expressed doubt about the truth of a statement, but if we are not ready to question this statement or believe that the doubt can be misinterpreted by others, then we can only resort to post-irony as a way to demonstrate our reaction with having a roundabout way. In fact, post-irony becomes a way of si- 
multaneously expressing both support and doubt, reducing the likelihood of backlash in either case. (Konstantinou, 2017). A. V. Pavlov rightly notes that post-irony should not be seen as a manifestation of "new sincerity" as a way to overcome the postmodern critical view, since post-irony is a kind of cultural phenomenon generated by the features of modern media space and inextricably connected with the specific position of a person in this space (Pavlov, 2019, pp. 24-25).

How did memes about Chapaev formulate a post-ironic attitude to the Black Lives Matter movement? To do this, it is necessary to disassemble several of the most common memes that combine the image of Chapaev with the symbols of BLM. For example, one of the simplest but common variations of the meme is the poster of the film itself, depicting Chapaev pointing his hand forward. Unlike the original poster of the film, the meme is accompanied by the words "Black Lives Matter," which symbolically recodes the alleged enemies, and the character is portrayed as an undeniable ally of the movement, which gives the image a post-ironic effect.

A more complex meme containing a direct reference to the image of Chapaev is the imposition of the faces of Hollywood actors of African American descent Morgan Freeman and Willard Carroll "Will" Smith on the frame from the film "Chapaev", and to whom Chapaev's key quote is attributed: "Oh, Petka, here we will break up the "whites", what kind of life will come". This meme acquires a post-ironic character precisely because the quote, instead of Chapaev, is attributed to the representatives of the African-American community. Not only does it make us perceive the "whites" in the literal meaning of the word, but also create the effect of the uncertain attitude of the author of the meme to the depicted situation. The rest of the memes on this topic are variations of the ones analyzed above and it eliminates the need to analyze them in detail.

It is easy to note that in the analyzed Internet memes there is a final break in the image of Chapaev with the post-memory of the Civil War. The very demand for this image in a fundamentally different political and cultural context demonstrates not only its unique plasticity, but also important laws regarding the collective memories of modern Russian society.

\section{CONCLUSIONS}

The image of Chapaev demonstrated a unique plasticity, having survived the transformation from a Soviet epic hero to a character of anecdotes and then Internet-memes. From a socio-philosophical and political point of view, the history of the evolution of this image is important as an illustration of the patterns of change in Russian society in memory of the Civil War. 
At the first stage, which occurred at the time of the formation of the Soviet state and the personality cult of I.V. Stalin, the Civil War acts simultaneously as a "myth of foundation," but also as a crowded out collective trauma. Displacement can be understood here both literally (leaving several million people outside Russia) and symbolically (displacement from the memory of not only ideological opponents of the new regime, but also those participants in the Civil War who did not fit into the contours of the new political order). Chapaev turns into an epic character, the function of which is to sacralize the existing order, and the tragic death acts as a sacrifice.

The second stage coincides with the period of the "thaw" and the formation of the era of "developed socialism," when the de-trumatization of the Civil War is achieved due to two main factors. Firstly, a traumatic narrative of repression is formed and, in parallel with it, a heroic narrative of the Great $\mathrm{Pa}$ triotic War, against the background of which the Civil War loses its tragedy. Secondly, the communicative memory of eyewitnesses and participants in the war is replaced by post-memory, reflected in artistic and cinematic texts that smooth out the sharpness of the contradictions between the "red" and "white." The image of Chapaev is discredited, which is manifested in the emergence of numerous anecdotes. In the situation of post-folklore, on the one hand, the frank ideologization of the image disappears, and on the other, the ironic nature of Chapaev's placement in new cultural contexts (a trip to the United States, etc.) becomes an instrument of desacralization of the political regime. Irony becomes a tool for overcoming collective trauma, which is facilitated by the very image of Chapaev, which is not related to the new traumatic narrative.

The third stage is connected with the post-Soviet period of the existence of Russian society, when the theme of the Civil War ceases to be a significant source of collective identity and a resource for stabilizing/destabilizing the political order. Despite attempts by the Russian authorities to establish a symbolic connection between the reconciliation of the "Reds" and "Whites" and overcoming internal social and cultural divisions in modern Russian society, the images of the Civil War are losing their relevance. Memory finally turns into a post-memory, operating only in a few images that fit into the modern cultural agenda.

The paradox of the situation is that the modern memorial landscape of Russian society makes the figure of Chapaev irrelevant as a character of the Soviet revolutionary myth. But the common visual image generated by the film acquires a completely different cultural and political significance, becoming the object for creating ironic and post-ironic memes. It can be stated that such a transformation testifies to Chapaev's final transition from the cultural 
memory of Russian society to the state of post-memory, which, however, does not prevent the preservation of particular family discourse.

\section{ACKNOWLEDGEMENTS}

The reported study was funded by RFBR and EISR according to the research project № 20-011-31600.

\section{References}

Anikin, D. A. (2020). Transfer of the past: cultural memory in conditions of migratory flows. Bulletin of Tomsk State University, (452), 66-72. (In Russian).

Arkhipova, A. S. (2003). Anecdote and his prototype: the genesis of the text and the formation of the genre. Moscow: Publishing House of the Russian State Humanitarian University. (In Russian).

Arkhipova, A. S. (2020, February 6). Anecdotes about Chapaev allowed Soviet citizens to laugh at everything sacred. Retrieved from Business FM St. Petersburg website: https://bfmspb.ru/novosti/aleksandra-arxipova-anekdotyi-pro-chapaeva-pozvolyalisovetskim-grazhdanam-smeyatsya-nad-vsem-sakralnyim (In Russian).

Bakhtin, M. M. (2020). The work of Francois Rabelais and the folk culture of the Middle Ages and the Renaissance. Moscow: Science. (In Russian).

Bykov, D. L. (2020, October 11). And ahead of Chapaev on a dashing horse. Retrieved from Sobesednik website: https://sobesednik.ru/obshchestvo/20 201005 -a-vperedi-chapaev-na-lihom-kon (In Russian).

Clark, K. (2002). The Soviet novel: history as ritual. Ekaterinburg: Ural University Publ. (In Russian).

Connerton, P. (2008). Seven types of forgetting. Memory Studies, 1(1), 59-71. doi: $10.1177 / 1750698007083889$

Dorson, R. (2004). Fakelore. In A. Dundes (Ed.), Folklore: Critical Concepts in Literary and Cultural Studies (pp. 281-289). New York: Routledge.

Fedor, J. (2017). Introduction: War and memory in Russia, Ukraine, and Belarus. In J. Fedor, M. Kangaspuro, J. Lassila, \& T. Zhurzhenko (Eds.), War and memory in Russia, Ukraine, and Belarus (pp. 1-40). London: Palgrave Macmillan.

Gramatchikova, N. B., \& Khoruzhenko, T. I. (2017). Postfolklore and internetlor. Yekaterinburg: Publishing House of Ural University. (In Russian).

Hirsch, M. (2012). The Generation of Postmemory: Writing and Visual Culture After the Holocaust. New York: Columbia University Press.

Hudak, D. A., Dale, J. A., Hudak, M. A., \& DeGood, D. E. (1991). Effects of Humorous Stimuli and Sense of Humor on Discomfort. Psychological Reports, 69(3), 779-786. doi: 10.2466/pr0.1991.69.3.779 
Konstantinou, L. (2017). Four faces of postirony. In R. van den Akker, A. Gibbons, \& T. Vermeulen (Eds.), Metamodernism: Historicity, affect, and depth after postmodernism. London; New York: Rowman \& Littlefield.

Koposov, N. E. (2011). High security memory: History and politics in Russia. Moscow: New Literary Review. (In Russian).

Laruelle, M. (2019). Commemorating 1917 in Russia: Ambivalent State History Policy and the Church's Conquest of the History Market. Europe-Asia Studies, 71(2), 249-267. doi: 10.1080/09668136.2018.1552922

Linchenko, A., \& Anikin, D. (2020). The political uses of the past in modern Russia: The images of the October revolution 1917 in the politics of memory of Russian parties. European Politics and Society, 21(3), 356-370. doi: 10.1080/23745 118.2019.1645430

Malinova, O. Yu. (2018). The commemoration in Russia of the centenary of the 1917 revolution(s): Analysis of strategies of the key mnemonic actors. Polis. Political Studies, (1), 9-25. doi: 10.17976/jpps/2018.01.02 (In Russian).

Neklyudov, S. Y. (2016). A few words about "postfolklore". Retrieved from Folklore and postfolklore: structure, typology, semiotics website: http://www.ruthenia.ru/folklore/ postfolk.htm (In Russian).

Neklyudov, S. Y. (1995). After folklore. Living antiquity, (1), 2-4. (In Russian).

Nevo, O., Keinan, G., \& Teshimovsky-Arditi, M. (1993). Humor and pain tolerance. HUMOR, 6(1), 71-88. doi: 10.1515/humr.1993.6.1.71

Nora, P. (1999). Between memory and history, the problems of places. In France-Memory (pp. 17-50). St. Petersburg: St. Petersburg University Press.a. (In Russian).

O’Donoghue, S. (n.d.). Postmemory as Trauma? Some Theoretical Problems and Their Consequences for Contemporary Literary Criticism. Retrieved from Politika website: https://www.politika.io/fr/notice/postmemory-as-trauma-some-theoretical-problems-and-their-consequences-for-contemporary

Odesskiy, M. P. (2007). Heroic myth about Chapaev. New look, (11). (In Russian).

Olick, J. K. (2016). The Sins of the Fathers: Germany, Memory, Method. Chicago: University of Chicago Press.

Olick, J. K., \& Robbins, J. (1998). Social Memory Studies: From "Collective Memory" to the Historical Sociology of Mnemonic Practices. Annual Review of Sociology, 24(1), 105140. doi: 10.1146/annurev.soc.24.1.105

Pavlov, A. V. (2019). Brave New "Digital World”: Postirony as a Value System of Millennials' Worldview. Horizons of humanitarian knowledge, (3), 16-31. doi: 10.17805/ ggz.2019.3.2 (In Russian).

Safronova, Yu. A. (2018). Third wave of memory studies: Twenty-three years against wool. Political Science, (3), 12-27. doi: 10.31249/poln/2018.03.01 (In Russian).

Schenk, F. B. (2007). Alexander Nevsky in Russian cultural memory: saint, ruler, national hero (1263-2000). Moscow: New Literary Review. (In Russian).

Seth, B. A. (1990). Cultural Analysis of the Russo-Soviet Anekdot. BA: University of Texas. 
Shcherbakova, E. (2020, November 11). opening of the Monument of Reconciliation is postponed. Retrieved from Sevastopol newspaper website: http://sevastopol.press/ 2020/11/11/otkrytie-pamjatnika-primirenia-otkladyvaetsja/ (In Russian).

Sherlock, T. (2007). Historical Narratives in the Soviet Union and Post-Soviet Russia: Destroying the Settled Past, Creating an Uncertain Future. New York: Palgrave Macmillan.

Vasiliev, Yu. (2020, November 4). Sladkov vs Chapaev: features of national reconciliation. Retrieved from Vzglyad website: https://vz.ru/society/2020/11/4/1068 927.html (In Russian).

Verch, J. (2018). Narrative tools, truth and quick thinking in national memory: the mnemonic confrontation between Russia and the West over Ukraine. Historical Expertise, (2), 15-32. doi: 10.31754/2409-6105-2018-2-15-32 (In Russian).

Werner, D. (2003, June 13). Anecdotes from Russia" and folklore of the Internet era. Retrieved from Russian magazine website: http://old.russ.ru/netcult/20 030617_verner.html (In Russian).

Zinovieva, N. A. (2016). Translation of sociocultural codes in the creation of an information product: analysis of Internet memes (PhD Thesis). St. Petersburg State University, St. Petersburg. (In Russian).

\section{Список литературы}

Connerton, P. (2008). Seven types of forgetting. Memory Studies, 1(1), 59-71. doi: $10.1177 / 1750698007083889$

Dorson, R. (2004). Fakelore. In A. Dundes (Ed.), Folklore: Critical Concepts in Literary and Cultural Studies (pp. 281-289). New York: Routledge.

Fedor, J. (2017). Introduction: War and memory in Russia, Ukraine, and Belarus. In J. Fedor, M. Kangaspuro, J. Lassila, \& T. Zhurzhenko (Eds.), War and memory in Russia, Ukraine, and Belarus (pp. 1-40). London: Palgrave Macmillan.

Hirsch, M. (2012). The Generation of Postmemory: Writing and Visual Culture After the Holocaust. New York: Columbia University Press.

Hudak, D. A., Dale, J. A., Hudak, M. A., \& DeGood, D. E. (1991). Effects of Humorous Stimuli and Sense of Humor on Discomfort. Psychological Reports, 69(3), 779786. doi: 10.2466/pr0.1991.69.3.779

Konstantinou, L. (2017). Four faces of postirony. In R. van den Akker, A. Gibbons, \& T. Vermeulen (Eds.), Metamodernism: Historicity, affect, and depth after postmodernism. London; New York: Rowman \& Littlefield.

Laruelle, M. (2019). Commemorating 1917 in Russia: Ambivalent State History Policy and the Church's Conquest of the History Market. Europe-Asia Studies, 71(2), 249-267. doi: 10.1080/09668 136.2018.1552922

Linchenko, A., \& Anikin, D. (2020). The political uses of the past in modern Russia: The images of the October revolution 1917 in the politics of memory of Russian parties. European Politics and Society, 21(3), 356-370. doi: 10.1080/23 745118.2019 .1645430 
Nevo, O., Keinan, G., \& Teshimovsky-Arditi, M. (1993). Humor and pain tolerance. HUMOR, 6(1), 71-88. doi: 10.1515/humr.1993.6.1.71

O’Donoghue, S. (n.d.). Postmemory as Trauma? Some Theoretical Problems and Their Consequences for Contemporary Literary Criticism. Retrieved from Politika website: https://www.politika.io/fr/notice/postmemory-as-trauma-some-theoretical-problems-and-their-consequences-for-contemporary

Olick, J. K. (2016). The Sins of the Fathers: Germany, Memory, Method. Chicago: University of Chicago Press.

Olick, J. K., \& Robbins, J. (1998). Social Memory Studies: From "Collective Memory" to the Historical Sociology of Mnemonic Practices. Annual Review of Sociology, 24(1), 105-140. doi: 10.1146/annurev.soc.24.1.105

Seth, B. A. (1990). Cultural Analysis of the Russo-Soviet Anekdot. BA: University of Texas.

Sherlock, T. (2007). Historical Narratives in the Soviet Union and Post-Soviet Russia: Destroying the Settled Past, Creating an Uncertain Future. New York: Palgrave Macmillan.

Аникин, Д. А. (2020). Трансфер прошлого: Культурная память в условиях миграционных потоков. Вестник Томского государственного университета, (452), 66-72.

Архипова, А. С. (2003). Анекдот и его прототип: Генезис текста и формирования жанра. Москва: Издательство РГГУ.

Архипова, А. С. (2020, февраль 6). Анекдоты про Чапаева позволяли советским гражданам смеяться над всем сакральным. Извлечено от Business FM Санкт-Петербург website: https://bfmspb.ru/novosti/aleksandra-arxipovaanekdotyi-pro-chapaeva-pozvolyali-sovetskim-grazhdanam-smeyatsya-nadvsem-sakralnyim

Бахтин, М. М. (2020). Творчество Франсуа Рабле и народная культура средневековья и Ренессанса. Москва: Наука.

Быков, Д. Л. (2020, октябрь 11). А впереди Чапаев на лихом коне. Извлечено от Собеседник website: https://sobesednik.ru/obshchestvo/20 201005 -a-vperedichapaev-na-lihom-kon

Васильев, Ю. (2020, ноябрь 4). Сладков против Чапаева: Особенности национального примирения. Извлечено от Взгляд website: https:/vz.ru/society/ 2020/11/4/1 068 927.html

Вернер, Д. (2003, июнь 13). «Анекдоты из России» и фольклор интернетовской эпохи. Извлечено от Русский журнал. website: http://old.russ.ru/netcult/ 20030617 _verner.html

Верч, Дж. (2018). Нарративные инструменты, истина и быстрое мышление в национальной памяти: Мнемоническое противостояние между Россией и Западом по поводу Украины. Пер. С англ. С. Е. Эрлих. Историческая Экспертиза, (2), 15-32. doi: 10.31754/2409-6105-2018-2-15-32 
Граматчикова, Н. Б., \& Хоруженко, Т. И. (2017). Постфольклор и интернетлор. Екатеринбург: Издательство Уральского университета.

Зиновьева, Н. А. (2016). Трансляция социокультурных кодов в создании информационного продукта (анализ интернет-мемов) (Автореферат диссертации). Санкт-Петербургский государственный университет, Санкт-Петербург.

Кларк, К. (2002). Советский роман: История как ритуал. Екатеринбург: Издательство Уральского университета.

Копосов, Н. Е. (2011). Память строгого режима. История и политика в России. Москва: Новое литературное обозрение.

Малинова, О. Ю. (2018). Коммеморация столетия революции(й) 1917 года в РФ: Анализ стратегий ключевых мнемонических акторов. Полис. Политические исследования, (1), 9-25. doi: 10.17976/jpps/2018.01.02

Неклюдов, С. Ю. (1995). После фольклора. Живая Старина, (1), 2-4.

Неклюдова, С. Ю. (2016). Несколько слов о «постфольклоре». Извлечено от Фольклор и постфольклор: Структура, типология, семиотика website: http://www.ruthenia.ru/folklore/postfolk.htm

Нора, П. (1999). Между историей и памятью, проблематика мест. В ФранцияПамять (сс. 17-50). Санкт-Петербург: Издательство Санкт-Петербургского университета.

Одесский, М. П. (2007). Героический миф о Чапаеве. Новый взгляд, (11).

Павлов, А. В. (2019). Дивный, новый «цифровой мир»: Постирония как ценностная установка мировоззрения миллениалов. Горизонты гуманитарного знания, (3), 16-31. doi: 10.17805/ggz.2019.3.2

Сафронова, Ю. А. (2018). Третья волна memory studies: Двадцать три года против шерсти. Политическая Наука, (3), 12-27. doi: 10.31249/poln/2018.03.01

Шенк, Ф. Б. (2007). Александр Невский в русской культурной памяти: Святой, правитель, национальный герой (1263-2000). Москва: Новое литературное обозрение.

Щербакова, Е. (2020, ноябрь 11). Открытие памятника Примирения откладывается. Извлечено от Севастопольская газета website: http://sevastopol.press/ 2020/11/11/otkrytie-pamjatnika-primirenia-otkladyvaetsja/ 